\title{
On clonogenic tumour cells and metastasis-forming cells
}

\section{Maurice Tubiana and Serge Koscielny}

We read with interest the paper by Michael Baumann, Mechthild Krause and Richard Hill on cancer stem cells (Exploring the role of cancer stem cells in radioresistance. Nature Rev. Cancer 8, 545-554 (2008)) ${ }^{1}$. We would like to make two remarks.

First, the authors list the terms used for designating cancer stem cells. However, they do not include those from the 1950s to the 1970s - colony-forming units and clonogenic cells - whereas a large number of papers used these terms. For example, we showed that the proportion of clonogenic cells in S phase can be determined by in vitro incubation with hydroxyurea ${ }^{2-4}$. The proliferation rate of clonogenic cells in a mammary tumour was measured following administration of hydroxyurea (5 mg per minute) or ionizing radiation $(0.3 \mathrm{~Gy})$. The changes in the labelling index and the mitotic index of the tumour cell population were different from those of the proportion of clonogenic cells in S phase. These differences were derived from differences between the cell cycle times of the clonogenic and the non-clonogenic tumour cell $^{3,4}$. In addition, a significant recruitment of quiescent clonogenic cells into the proliferative compartment about 5 hours after administration of hydroxyurea was observed $^{4}$. After irradiation, blocks at G1/S and S/G2 phases of the cell cycle induced a semi-synchronization of clonogenic tumour cells that lasted approximately two cell cycles. These studies remain valid and are probably relevant for cancer stem cells.

Second, we studied the proportion of stem cells in the population of tumour cells in human breast cancer during tumour growth ${ }^{5-7}$. We assumed that the probability of distant metastatic dissemination during tumour growth is correlated to the number of metastasis-forming cells (probably stem cells). In tumours $10 \mathrm{~mm}$ in diameter the maximum number of cells is $0.5 \times 10^{9}$ (REF. 7). Metastases were present or developed after the removal of the tumour in $11 \%$ of the patients ${ }^{5,6}$. This corresponds to a probability of distant metastatic dissemination of $20 \%$ per $10^{9}$ cells during this period.

For tumours from 10 to $20 \mathrm{~mm}$ in diameter, the maximal number of cells is $4.2 \times 10^{9}$ and the proportion of patients with metastases increased by $16 \%$. During this growth from $0.5 \times 10^{9}$ cells to $4.2 \times 10^{9}$ cells, the probability of distant dissemination is $3.9 \%$ per $10^{9}$ cells. For tumours from 20 to $30 \mathrm{~mm}$ in diameter, that is from $4.2 \times 10^{9}$ to $14.1 \times 10^{9}$ cells, the number of patients with metastases increased by $13 \%$ and the probability per $10^{9}$ cells is $0.9 \%$. During the growth from $30 \mathrm{~mm}$ to $40 \mathrm{~mm}$ $\left(14.1 \times 10^{9}\right.$ and $33.5 \times 10^{9}$ cells $)$ these values are $10 \%$ and $0.3 \%$, respectively. The proportion of metastasis-forming cells further decreases to $0.3 \%$ and to $0.1 \%$ for tumours 40 and $50 \mathrm{~mm}$ in diameter. Hence the proportion of metastasis-forming cells is much higher in small tumours and their number is nearly constant thereafter. For tumours of less than $30 \mathrm{~mm}$ in diameter the proportion of metastasis-forming cells is about 2-fold higher in grade 2 tumours than in grade 1 , and slightly greater in grade 3 tumours.

Thus, the proportion of stem cells varies widely with various factors, which should be taken into account when discussing therapeutic implications.

Maurice Tubiana is at the Gustave Roussy Institute, Villejuif, France and Serge Koscielny is at the Department of Epidemiology. Gustave Roussy Institute, Villejuif, France. Correspondence to M.T. e-mail: maurice.tubiana@univ-paris5.fr

Baumann, M., Krause, M. \& Hill, R. Exploring the role of cancer stem cells in radioresistance. Nature Rev. Cancer 8, 545-554 (2008).

2. Rockwell, S., Frindel, E. \& Tubiana, M. A technique for determining the proportion of the clonogenic cells in $S$. phase in EMT6 cell cultures and tumours. Cell Tissue Kinet. 9, 313-323 (1976).

3. Rockwell, S., Frindel, E., Valleron, A. J. \& Tubiana, M. Cell proliferation in EMT6 tumours treated with single dose of X-rays in hydroxyurea. Cell Tissues Kinet. 11, 279-289 (1978)

4. Demeestere, M., Rockwell, S., Valleron, A. J., Frindel, E. \& Tubiana, M. Cell proliferation in EMT6 tumors treated with single doses of X-rays or hyroxyurea. II computer simulations. Cell Tissues Kinet. 13, 309-317 (1980)

5. Tubiana, M., Koscielny, S. Natural history of human breast cancer: recent data and clinical implications. Breast Cancer Res. Treat. 18, 125-140 (1991).

6. Koscielny, S., Tubiana, M. The link between local recurrence and distant metastases in human breast cancer. Int. J. Radiat. Oncol. Biol. Phys. 43, 11-24 (1999).

7. Tubiana, M. \& Koscielny, S. Histoire naturelle du cancer du sein. Implications pour le dépistage et le traitement. Bull. Mém. Acad. Roy. Méd. Belge (Brussels) 160, 367-384 (2005) (in French). 